\title{
Aplikasi Teknologi Geospasial Berbasis Web Map Untuk Monitoring Bencana Epidemi Wabah Penyakit Covid-19 di Provinsi Riau
}

\author{
Giant Amor ${ }^{1}$, Natasya Febriani ${ }^{2}$, Arie Yulfa ${ }^{3}$ dan Triyatno ${ }^{4}$ \\ 1,2 Program Studi Pendidikan Geografi, Universitas Negeri Padang \\ 3 Jurusan Geografi, Universitas Negeri Padang \\ ${ }^{4}$ Pasca Sarjana Ilmu Lingkungan, Universitas Negeri Padang \\ e-mail: giantamor84@gmail.com
}

\begin{abstract}
Abstrak : Dimulai revolusi industri 4.0 terjadinya perkembangan teknologi yang sangat pesat salah satunya dibidang informasi geospasial. Pemanfaatan teknologi sistem informasi geografis (SIG) sudah merambah pada berbagai aspek kehidupan. SIG juga sangat berkontribusi dalam perkembangan peradapan di kota-kota besar yang telah bertransformasi menjadi smart city. Keterbukaan informasi merupakan bahagian utama yang menjadi sasaran perkembangan smart city. Tujuan dalam penelitian ini untuk mengengaplikasikan dan mengembangkan teknologi SIG berbasis Web Map dalam memetakan perseberan pasien covid 19 di Provinsi Riau. Melakukan uji kecepatan browser untuk mengakses web map informasi Covid 19. Dalam penelitian ini dilakukan inventaris data berbasis cloud data spasial, perangkat yang digunakan berupa ArcSIGPro untuk membangun webmap. Hasil dari penelitian ini ditemukan perkembangan jumlah pasien Covid-19 yang terus berkembang setiap waktu, yang direpresentasikan dalam informasi lokasi. Tampilan akir web map ini dapat di akses melalui link https://bit.ly/31EKXSW. Penggunaan WebSIG ini mampu memamaparankan informasi covid dengan sistem webmap lebih efisien untuk mengetahui spot -spot yang memiliki jumlah korban yang relative tinggi, secara umum untuk kesemua jenis kasus Covid-19 tersebar banyak kasus pada wilayah administrasi Kabupaten Rokan Hulu, Rokan Hilir, Indragiri Hulu dan Indragiri Hilir. Sedangkan untuk kasus positive covid-19 terbesar tersebar di wilayah Kota Pekanbaru dengan jumlah 40 orang.
\end{abstract}

Kata Kunci : Bencana, Wabah penyakit, Web-Map, Covid-19

\section{PENDAHULUAN}

Peranan Tekonologi sistem informasi geografis (SIG) Sebagai alat untuk memetakan suatu fenomena dan gejala geografis sudah sangat terasa, yangmana peran penting dalam memfasilitasi informasi spasial yang bersifat keruangan merepresentasikan suatu lokasi yang berguna serta bermanfaat bagi kehidupan umat manusia. Informasi spasial dalam bentuk data digital yang diperoleh melalui berbagai metode pengumpulan data, baik secara primer melalui proses survey ataupun dengan model sekunder melalui intrepetasi data satelit, dan atau bersumber dari data lain yang bisa dispasialkan. Analisis SIG memerlukan tenaga ahli sebagai interpreter, perangkat keras komputer dan software pendukung (Nuarsa, 2004., dalam Amalia, 2014). Sistem informasi geografis memiliki kelebihan dalam pengolahan data seperti; perolehan dan verifikasi, kompilasi, penyimpanan, pembaruan dan editing, manajemen dan pertukaran, manipulasi, penyajian dan analisis (Tor Bernhardsen,1992., dalam Amalia, 2014). Pendekatan analisis spasial sangat efisien untuk menakar gejala secara empiris dalam memahami interaksi dalam fenomena geografis, tidak hanya itu pendekatan ini juga mampu meakukan prediksi dari data yang diintegrasikan yang mana mampu menjelaskan interaksi dan gejala spasial (Tobler Waldo, 1976, Hanif, et.al, 2019). Terintegrasinya sistem informasi geografis dengan data pengindraan jauh dan data lainya dalam sistem could data, dan dianalisis dengan berbagai algoritma, lebih efektif dalam 
menganalisis gejala keruangan dan direpesentasikan secara digital (Rahman, et.al. 2020, Hidayat, 2020).

Menurut BNPB Bencana di Indonesia terdiri atas beberapa jenis diantaranya yaitu: angin puting beliung, tsunami, gelombang ekstrem, baniir, tanah longsor, kegagalan teknologi dan epidemic wabah penyakit (BNPB, 2012). Epidemiologi adalah salah satu ilmu yang mempelajari mengenai pola penyebaran penyakit dan kejadian, yang mana ini berhubungan dengan kesehatan dan factor yang mempengarui fenomena tersebut, sedangkan wabah penyakit, terjadi ketika suatu penyakit mulai menular dan tersebar kepada banyak populasi penduduk dengan jumlah meningkat daripada biasanya, di dalam suatu wilayah, zona, atau komunitas atau saat periode tertentu. Wabah biasanya berlangsung dalam rentang waktu jangka panjang, ini dimulai dari hitungan hari hingga tahun. Tidak hanya di satu wilayah, tetapi wabah juga bisa meluas ke berbagai Negara.

Web SIG dalam bidang kebencanaan mampu menjadi rujukan sebagai early warning system karena mampu menangani data dalam bentuk ruang (Ilamadina, 2012, Pratama, 2017). Dewasa ini Negara-negara di dunia menghadapi bencana pandemic Covid-19 yang melanda hampir seluruh belahan Negara di dunia. Outbreak COVID-19 telah dideklarisasikan oleh WHO sebagai Darurat Kesehatan Masyrakat secara global (Global Public Health Emergency) pada 30 Januari 2020 (WHO, 2020). Coronavirus adalah jenis Virus yang menyebabkan Penyakit mulai dari gejala ringan sampai berat. Ada setidaknya dua jenis coronavirus yang diketahui dapat menyebabkan penyakit dengan gejala berat seperti Middle East Respitory Syndrome (MARS) dan Severe Acute Respitary Syndrome (SARS). Coronavirus Disaese 2019 (COVID-19) adalah penyakit jenis baru yang belum pernah teridentifikasi sebelumnya pada manusia. Oleh karena itu menjadi perhatian kita sebagai pemerhati SIG untuk dapat berkontribusi dalam memetakan kasus covid-19 di lingkungan tempat tinggal kita berada. Covid-19 merupakan ineksi baru yang mengakibatkan orang yang terinveksi mengalami gangguan pernapasan, terhitung 2 maret 2020 korban dari covid ini mencapai 90.308 orang (Yuliana, 2020). Berdasarkan Data Kemenkes Juni 2020 terkait Penyebaran kasus covid-19 (Kmk No. Hk. 01.07-Menkes-413- TentangPedoman-Pencegahan Pengendalian Covid19). Kemenkes membagi kasus peneyebaran covid-19 menjadi beberapa jenis diantaranya (ODP,PDP,dan Positif) ODP Merupakan Orang Dalam Pengawasan,/Pemantauan yang disebabkan beberapa Faktor diantaranya ; Subjek sedang melakukan Mobilisasi yang cukup tinggi contohnya Keluar Kota, Berkontak fisik relative dekat dengan penderita covid-19 dsb. Sementara PDP adalah Pasien Dalam Pengawasan, yang menunjukkan gejala mirip covid-19. Dan Positif merupakan orang yang telah divonis terjangkit virus covid-19 oleh tes yang dilakukan (Rapid test, dan Tes Swab,). Informasi terkait kasus bencana epidemi wabah penyakit covid-19 yang dilaporkan pada media massa seperti TV sudah sangat jamak disaksikan oleh masyarakat namun informasi yang disampaikan terkadang masih belum menampilkan peta yang menginterpretasi daerah yang menjadi titik kasus covid-19 serta tidak semua orang dapat menyaksikan berita di TV terkait informasi covid-19 akibat kesibukan masing masing individu. tentunya kondisi ini kurang baik dalam penyampaian informasi terkait, sebab dapat menyebabkan miss informasi.

Advance teknologi SIG dalam model sistem Web Map hadir dalam bentuk informasi data spasial yang memudahkan pengguna untuk berbagi informasi terkini dengan membagikan link yang telah dibuild pada Software Arc-SIG Pro sebagai platfrom induk dan membagikan pada Media Social seperti ("WA,Ig,Fb,Twitter,dll). Pengguna dapat mengakses Web Map kapan saja dan dimana saja, asalkan terkoneksi internet. Penggunaan pertama SIG bidang kesehatan dipelopori oleh John Snow ketika membuat peta kematian kolera pada saat terjadinya wabah kolera pada abad 19. Aplikasi ini dirancang dan dibangun dengan menggunakan software ArcSIG yang memiliki kemampuan untuk menvisualisasikan, meng-explore, menjawab query (baik basis data spasial maupun non spasial) (Islamadina dan Nasarudin, 2012).

SIG berbasis web merupakan sebuah aplikasi sistem informasi geografis yang dapat dijalankan dan diaplikasikan pada suatu web browser. Aplikasi tersebut bisa dijalankan dalam 
suatu jaringan global yaitu internet, dalam suatu jaringan lokal ata jaringan LAN, dan dalam suatu komputer yang memiliki web server (Prahasta, 2007., dalam Yuliani, 2016).

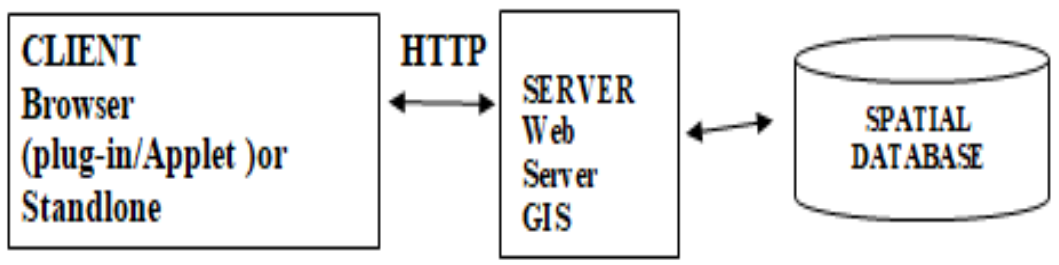

Gambar 1 Arsitektur Sistem WebSIG (Prahasta,2009., dalam Yuliani, 2016.

Sebagaimana topik yang di bahas dapat digunakan oleh tenaga kesehatan masyarakat dan para profesional, terutama pembuat kebijaksanaan, orang-orang statistik, epidemiologi, regional dan para petugas daerah medis (Jasmin and Johnson,1999., dalam Amalia, 2014). Maka dari itu peranan SIG bagi kehidupan umat manusia inilah perlu adanya pembahasan mendalam mengenai Peranan Teknologi SIG dalam Monitoring Dinamika Covis-19, khususnya Wilayah Riau sebagai Studi kasus tulisan ini. Didasari oleh Peranan SIG yang begitu besar dalam menginterpretasikan data spasial inilah Penulis mencoba untuk mengembangkan ide serta pikiran agar dapat berkontribusi pada masa sekarang terutama dikondisi wabah (pandemic Covid1-19).

\section{METODE}

\subsection{Lokasi Penelitian}

Penelitian ini dilakukan di Provinsi Riau yang berada ditengah pantai timur Pulau Sumatera, yaitu disepanjang pesisir Selat Malaka. Provinsi Riau membentang dari lereng Bukit Barisan hingga Selat Malaka yang terletak antara $01^{\circ} 05^{\prime} 00^{\prime \prime} \mathrm{LS}-02^{\circ} 25^{\prime} 00^{\prime \prime} \mathrm{LU}$ dan $100^{\circ} 00^{\prime} 00^{\prime \prime}-$ $105^{\circ} 05^{\prime} 00^{\prime \prime} \mathrm{BT}$

\subsection{Alat dan Bahan Penelitian}

Dalam proses penelitian ini peneliti menggunakan berbagai jenis perangkat keras, perangkat lnak dan data yang dibutuhkan. Detail informasi dijelaskan sebagai berikut:

Tabel 1. Alat dan bahan

\begin{tabular}{|c|c|c|}
\hline $\begin{array}{cc}\text { Perangkat } & \text { Keras } \\
\text { (Hardware) }\end{array}$ & Perangkat Lunak (Software) & Data \\
\hline $\begin{array}{l}\text { a. Smartphone vivo (Y12 series) } \\
\text { b. Laptop Hp Core i5 } \\
\text { (NH4PQAUseries) } \\
\text { - Processor : } 2.16 \mathrm{GHz} \\
\text { - GPU : Intel Core i5-8265U } \\
\text { - Memory : } 4 \mathrm{~GB} \\
\text { - Storage : } 500 \mathrm{~GB} \text { hard disk }\end{array}$ & $\begin{array}{l}\text { a. Microsoft Word } 2016 \\
\text { b. Web App Arc-SIG Online } \\
\text { c. Maps } 2020 \\
\text { d. Mozilla Firefox 20.0.1 } \\
\text { e. ArcSIG Pro }\end{array}$ & $\begin{array}{l}\text { 1. Data Spasial } \\
\text { a. Peta Adm Riau } \\
\text { b. Koordinat Kasus Covid-19 } \\
\text { c. Koordinat puskesmas } \\
\text { 2. Data Non Spasial } \\
\text { a. Data covid-19 Riau } \\
\text { b. Peskesmas dititik } \\
\text { pelavanan Kesehatan Prov. Riau }\end{array}$ \\
\hline
\end{tabular}

\subsection{Tahapan Membangun Web Map}

2.3.1 Pengumpulan Data

Pada penelitian ini dilakukan dengan dua tahapan yaitu pengumpulan data dan pembuatan webSIG. Pengumpulan data dilakukan pada bulan Juni 2020 dan pembuatan web dilakukan setelah seluruh data terkumpul.

\subsubsection{Pembuatan basis data dan input data}

Pada bagian ini, Pembuatan basis data dilakukan melalui localhost di software Arc-SIG Pro sebagai aplikasi dalam pembuatan basis data covid-19 di wilayah Riau. Hal yang pertama kali dilakukan adalah login pada aplikasi Arc-SIG pro sebelum proses menginput data. Kemudian data yang telah diperoleh diolah menjadi data titik-titik persebaran kasus covid-19 yang diinterpretasikan dengan titik merah sebagimana gambar dibawah, setelah itu peta yang telah 
terinterpretasi dapat langsung dishare "share as web map pada menu bar yang terdapat di aplikasi Arc-SIG pro.
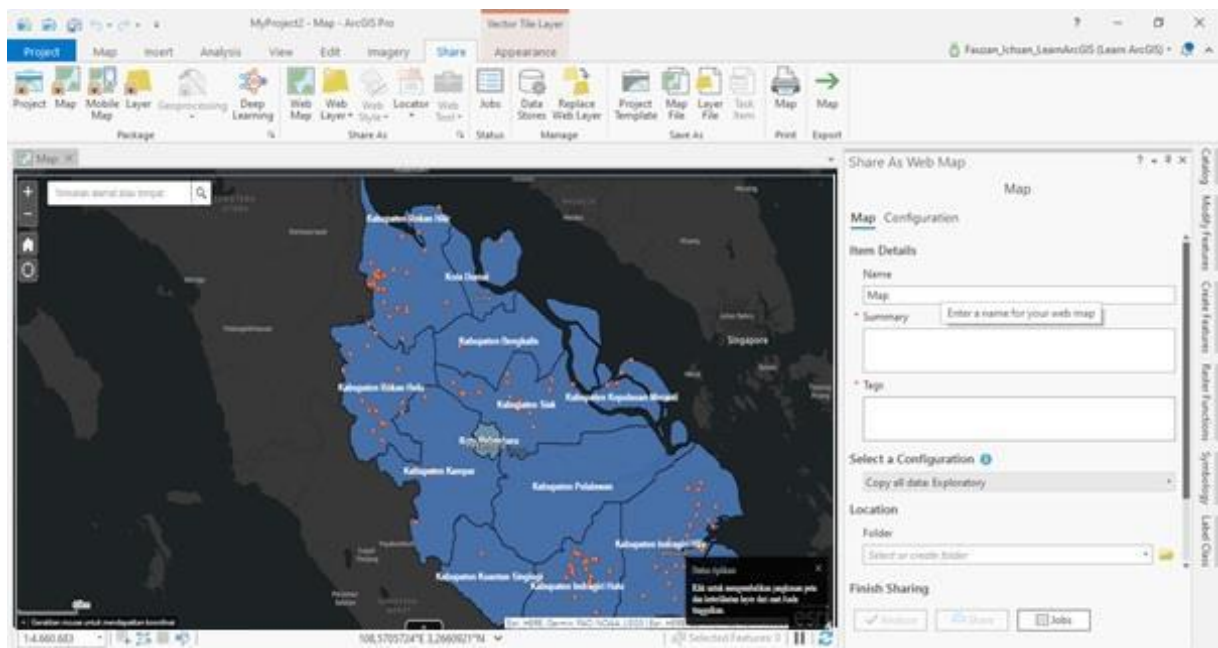

Setelah "share as web map" tadi selesai maka dilanjutkan dengan menshare kembali layer yang menjadi informasi yang telah kita rancang dengan tampilan seperti pada gambar dibawah ini

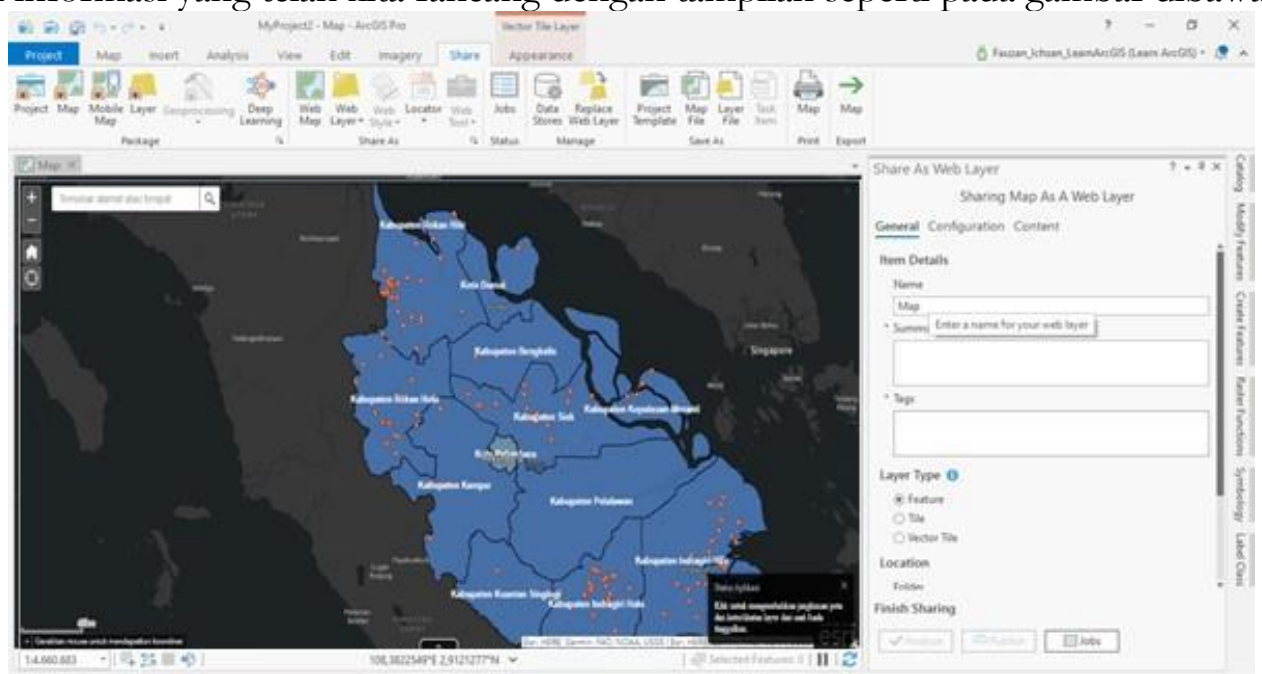

Setelah semua data diunggah ke laman web yang kita bangun maka selanjutnya ialah membuat aplikasi web agar dapat dibagikan kepada publik dan dapat diakses oleh siapa saja seperti pada gambar dibawah.

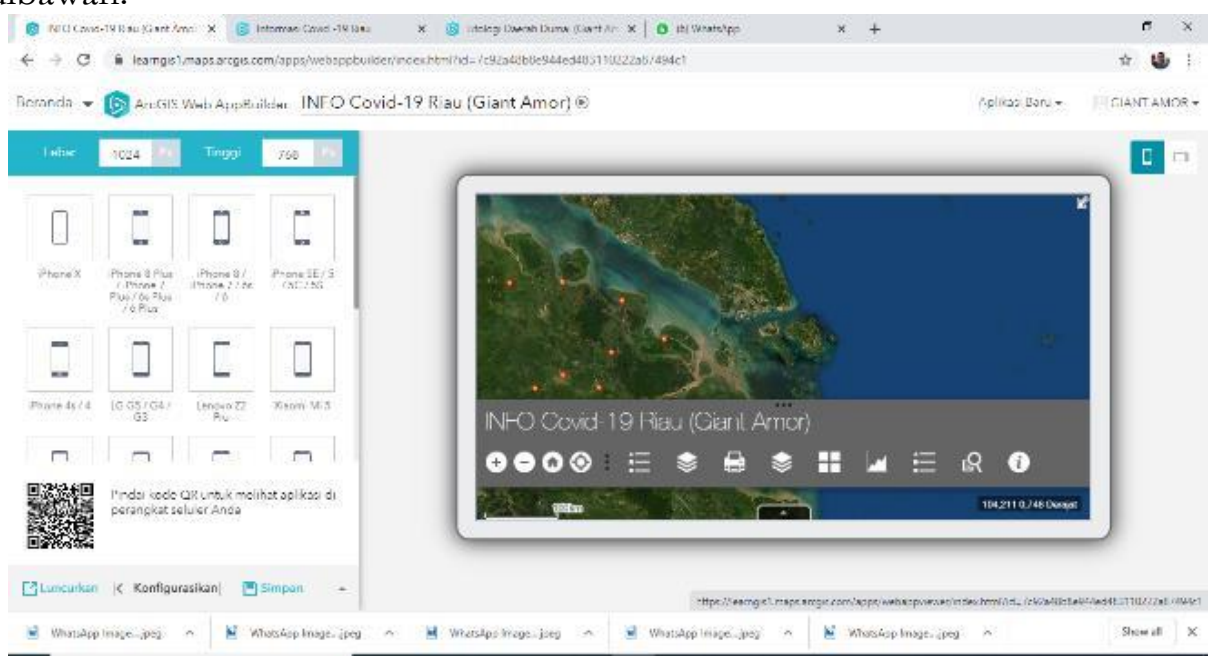




\subsection{Diagram Alir Proses Penelitian}

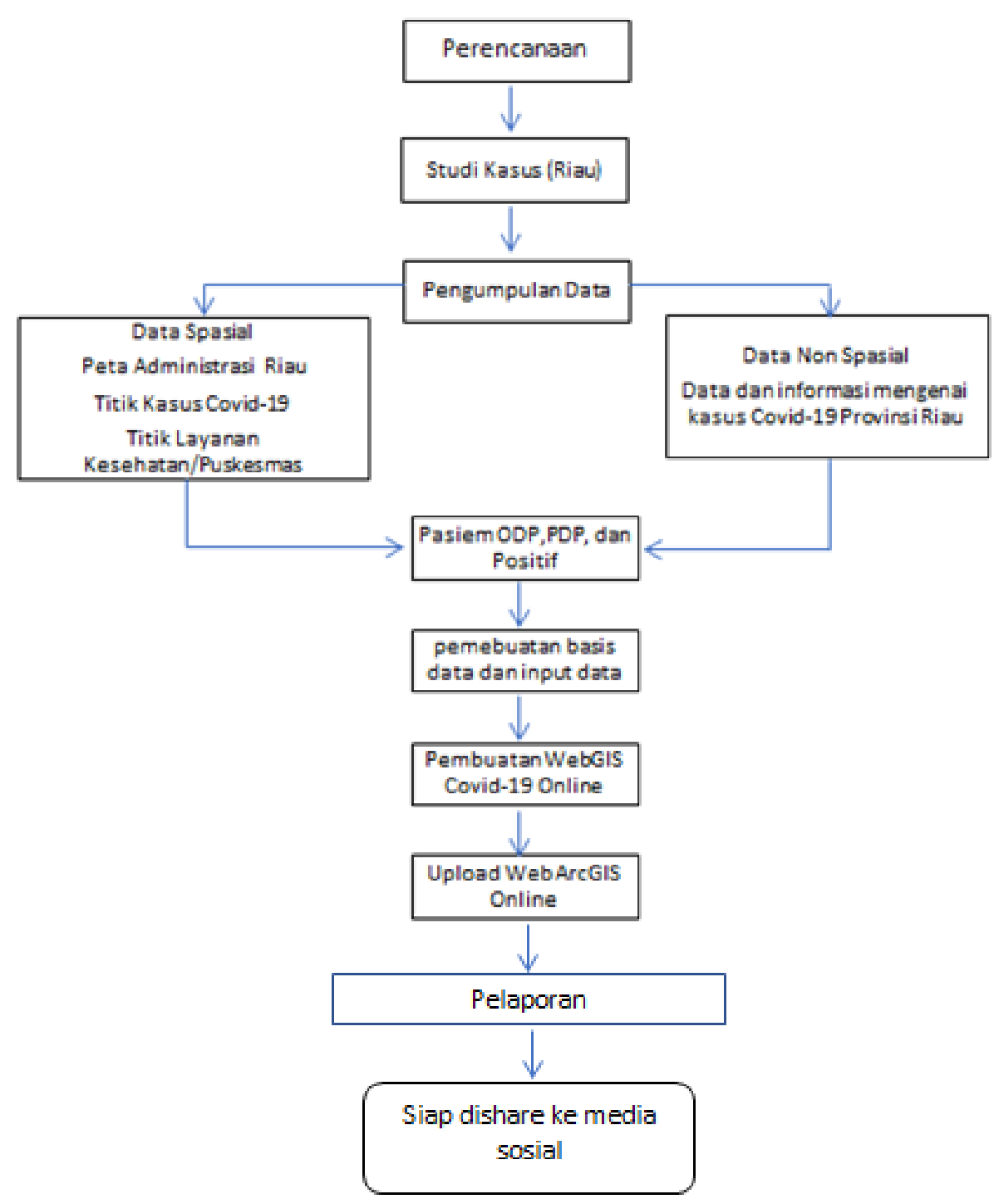

Gambar 2 Diagram Alir Penelitian

\section{HASIL DAN PEMBAHASAN}

Dari rancangan pembangunan web map untuk menginformasikan dan memonitoring bencana epidemic wabah penyakit Covid -19, maka peeliti berhasil menyelesaikan model web map yang mana web map ini flexible mampu di akses menggunaan teknologi smatpone/ android ataupun menggunakan computer/ pc jinjing. Data-data yang telah di input kedalam sistem web dan di integrasikan dengan cloud data lain, seperti google map, ataupun bing map. Gambar dibawah merupakan tamplilan awal pada layar smartphone pengakses ketika masuk kesitus aplikasi web map covid 19. Dengan dukungan teknologi Arcgis pro, mempercepat dan mempermudah dalam membangun webmap yang lebih interaktif. 

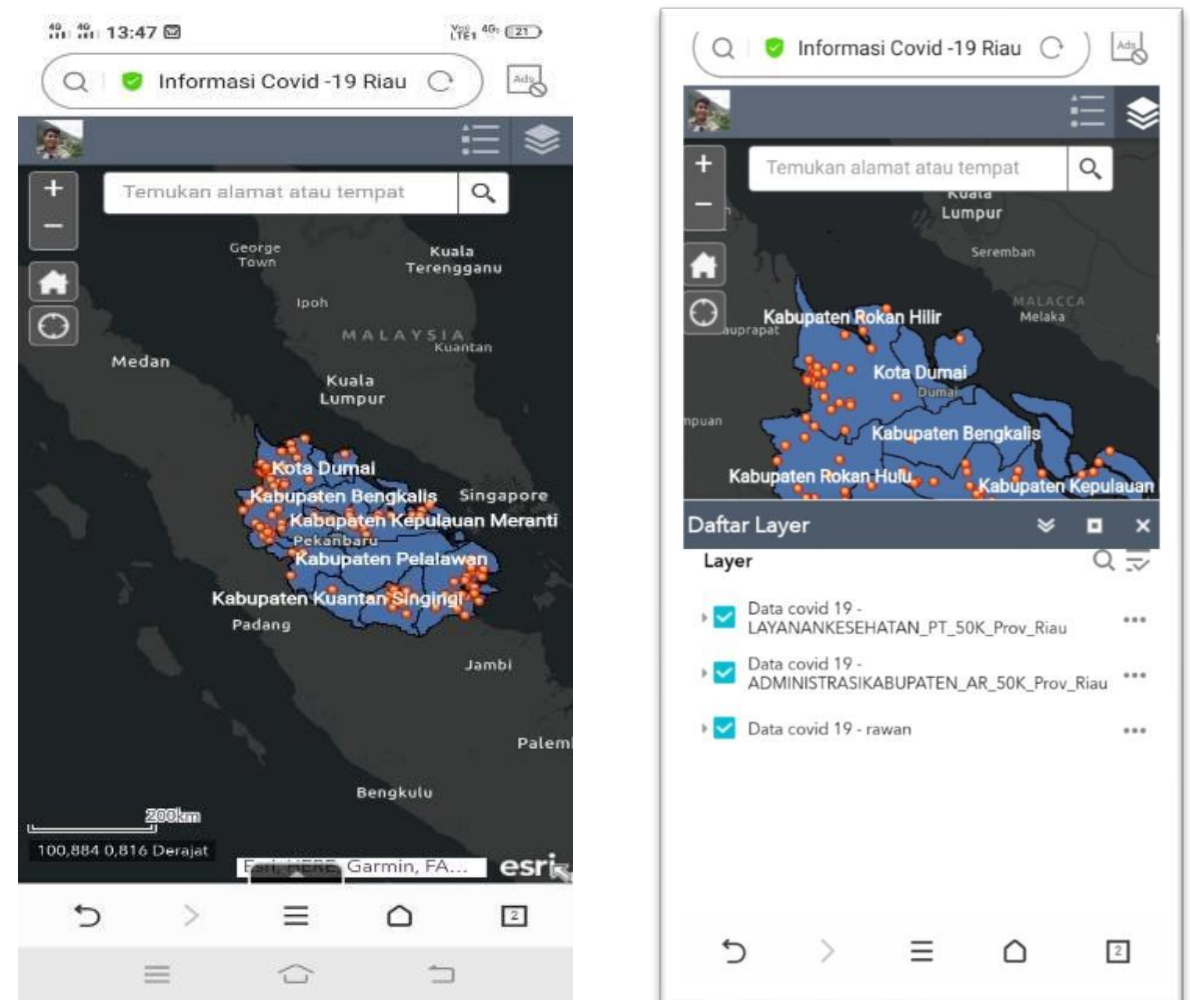

Gambar 3 Tampilan Awal WebSIG, Laptop, dan Pada smartphone

Tampilan Aplikasi SIG berbasis Web Tampilan Aplikasi SIG (Web-SIG) berbasis Web Map di Perangkat Pc/Laptop dan Android. Dalam mengakses laman apliaksi Web App ini pengguna dapat mengakses melalui link https://bit.ly/31EKXSW Sebagai aplikasi web berbasis data SIG laman app ini terbagi menjadi dua, yakni bagi Pengguna (Masyarakat) dan Perancang atau Admin dalam membangun data spasial Covid-19 ini. Hal ini memungkinkan adanya update data realtime yang dapat dilakukan oleh admin berdasarkan data yang ada. Sedangkan bagi pengguna (Masyarakat) hanya dapat membuka atau mengakses web app SIG ini melalui link yang dibagikan oleh pengguna lainnya Sebab masyarakat tidak dapat mengakses Halaman Adminstrator guna setting data, dikarenakan merekan tidak memiliki akun Arc-SIG Online. Berikut tampilan laman web app SIG bagi pengguna atau massyarakat melalui pc / laptop dan Handphone masing masing pengakses.
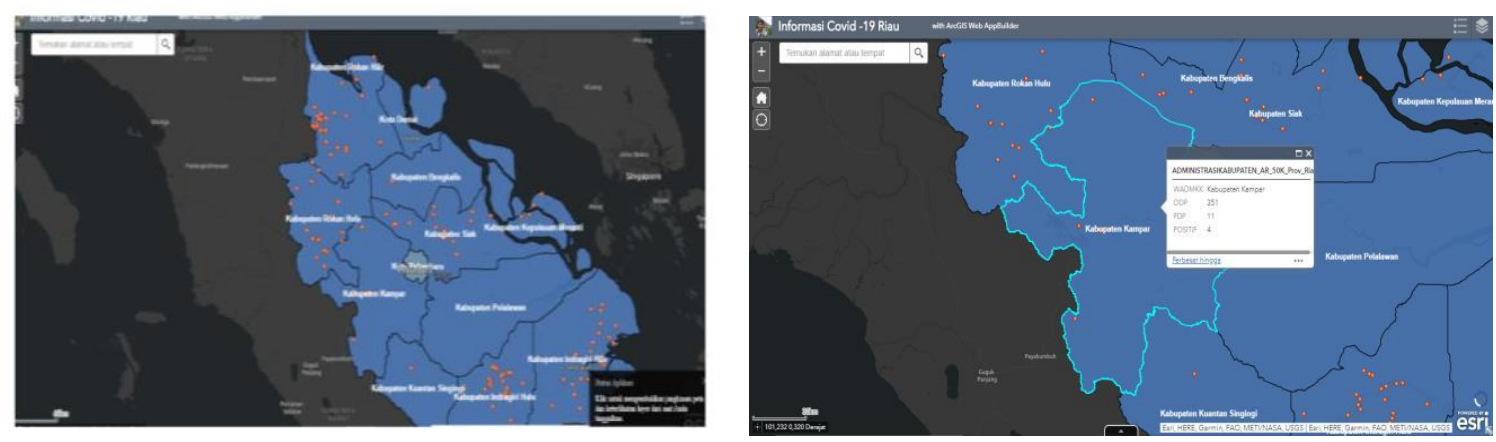

Gambar 4 Tampilan Informasi Aplikasi SIG berbasis WebSIG Covid-19.Pada PC 

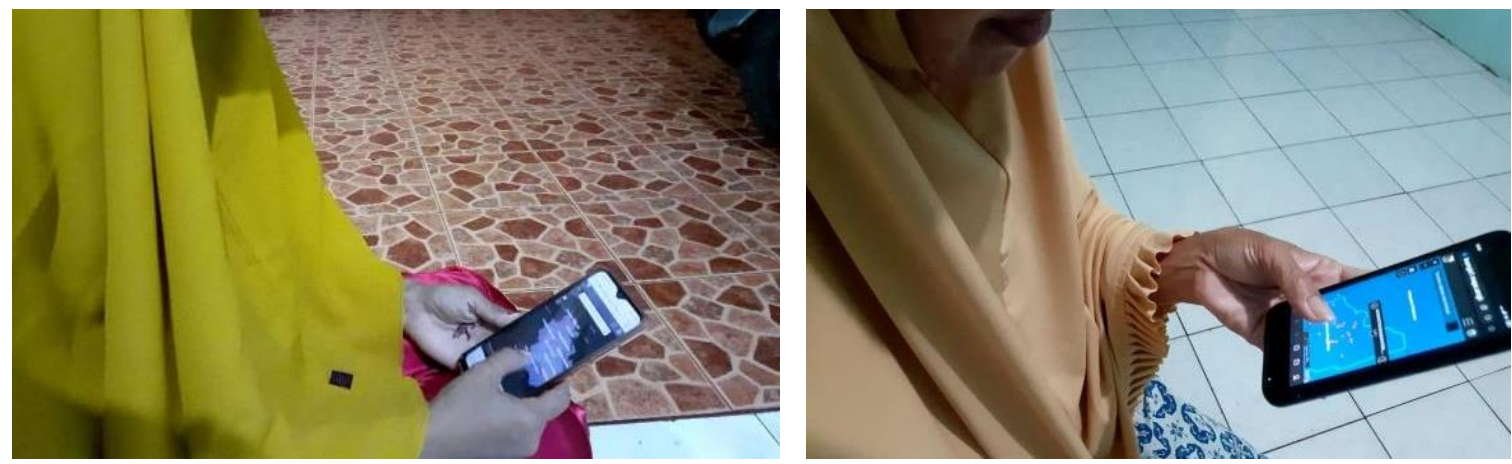

Gambar 5 Masyarakat Mengakses Link Persebaran Covid-19

Adanya aplikasi SIG berbasis web ini dapat digunakan untuk mendeskripsikan data penderita covid-19 atau orang dengan gejala atau pemantauan, (PDP,PDP) mengingat virus ini sangat cepat menular, dengan mengetahui persebaran virus ini diharapkan masyarakat agar tetap waspada dan mematuhi protokol kesehatan yang telah diterapkan oleh pemerintah untuk memutus rantai penyebaran. Oleh sebab itu dibutuhkan peran Geograf dalam memberikan kontribusi atau sumbangsih kepada bangsa dan negara sebagai upaya mendukung program pembangunan berkelanjutan. Data-data tersebut dapat dilihat lebih rinci dengan mengklik wilayah pemantauan (Regional) tertentu yang diinginkan oleh pengguna seperti tampilan pada gambar dibawah ini yang disajikan pada layer ialah Persebaran Titik penderita covid-19 per Regional Kabupaten / Kota Prov Riau.
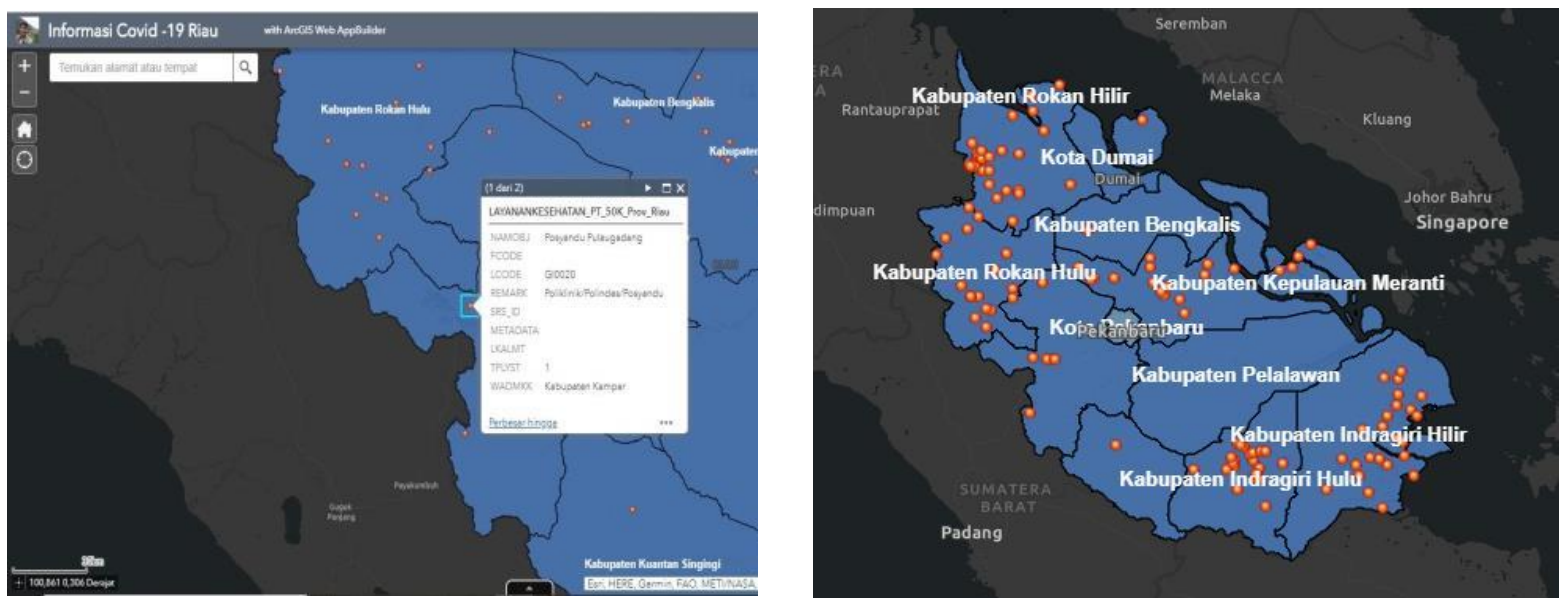

Gambar 6. Data Pasien Covid 19, dan informasi Layanan Kesehatan (Puskesmas disetiap kecamatan Prov.Riau)

Dari beberapa Tampilan aplikasi Web app yang disajikan oleh perangkat laptop ataupun hp android tersebut: a. Persebaran penderita Covid-19 di Provinsi Riau ini telah menyebar secara merata ke seluruh Kab / Kota yang ada (Gambar 7). Informasi Spasial berbasis Web app ini menjadi gambaran dalam melihat Dinamika kasus Covid-19 yang terjadi di Bumi Lancang Kuning ini. b. Adapun Data yang telah terangkum sejauh ini berdasarkan data yang tersedia pada web app ialah Hasil Rekapitulasi Pasien Covid-19 
Tabel 2 Hasil Rekap Pasien Covid-19, November 2020

\begin{tabular}{rllllc}
\hline NO & Kab / Kota & \multicolumn{2}{c}{ Rekap COVID 19 } & Provinsi Riau \\
Total
\end{tabular}

Dari tabel diatas, data covid menujukan distribusi pasien covid yang bervariasi di setiap wilayah. Jika di lihat dari total kasus kejadian covid baik dari status ODP,(Orang dalam Pemantauan PDP (Pasien Dalam Pengawasan) dan Positive Kemenkes RI 2020. Kota Pekanbaru berada pada posisi tertinggi memiliki status kasus 952. Pada peringkat kedua yaitu Kabupaten Rokan Hulu dengan total pasien 941, Sedangkan Indragiri Hulu dengan total kasus 589. kasus pasien covid positive terbesar berada di Kota pecan baru dengan jumlah pasien 40 orang, dan kedua berada di kabpaten Bengklalis dengan jumlah korban mencapai 14 orang, dan pa urutan ke tiga yaitu kabupaten Indragiri Hulu dengan umlah pasien positive mencapai 11 orang. Kita bisa melihat ada tiga reginal utama yang menjadi spot penyebaran kasus covid 19 di Provinsi Riau, spot ini tersebar di wilayah Utara tengah dan wilayah selatan. Menurut Mona, virus korona menular secara contagious element dalam sebuah jaringan dapat tertular dan saling menginfeksi. Peningkatan kasus virus korona dapat meningkat dalam waktu yang sangat cepat. virus ini dapat mudah menular melalui kontak dengan penderita (Mona, 2020).

\section{Pengujian Kecepatan Web Browser}

Berdasarkan hasil uji kecepatan akses Aplikasi Web Browser, membuktikan bahwa aplikasi webSIG dapat diakses melalui berbagai macam platform di perangkat pc (Mozilla firefox, Google Chrome, dan Internet explorer) ataupun smartphone android (Opera mini, UC Browser, Google Chrome). Mengenai kecepatan serta kelancaran mengakses aplikasi web SIG ini tergantung jaringan data yang digunakan oleh pengguna sebab masing masing penyedia layanan data internet memiliki kecepatan dan kelancaran yang berbeda- beda setiap aksebilitasnya. 
Error! No text of specified style in document.

Tabel 3 Hasil Pengujian Kecepatan Akses Intenet

\begin{tabular}{|c|c|c|c|c|c|c|}
\hline \multirow[t]{2}{*}{ No Menu } & \multicolumn{6}{|c|}{ Waktu (detik) Media Akses : Kartu Telkomsel } \\
\hline & $\begin{array}{r}\text { Opera } \\
\text { Mini }\end{array}$ & $\begin{array}{c}\text { Uc } \\
\text { Browser }\end{array}$ & $\begin{array}{l}\text { Google } \\
\text { Chrome }\end{array}$ & $\begin{array}{l}\text { Mozila } \\
\text { firefox }\end{array}$ & $\begin{array}{l}\text { Internet } \\
\text { Explorer }\end{array}$ & $\begin{array}{l}\text { Google } \\
\text { Chrome }\end{array}$ \\
\hline Halaman Beranda & $3,23 ”$ & $2,31^{\prime \prime}$ & $3,20^{\prime \prime}$ & $1,22^{\prime \prime}$ & $2,33^{\prime \prime}$ & $1,22^{\prime \prime}$ \\
\hline $\begin{array}{l}\text { Titik layanan } \\
\text { Kesehatan } \\
\text { (Puskesmas) }\end{array}$ & $2,33^{\prime \prime}$ & $2,22^{\prime \prime}$ & $2,11^{\prime \prime}$ & $1,33^{\prime \prime}$ & $1,32^{\prime \prime}$ & $2,21^{\prime \prime}$ \\
\hline $\begin{array}{ll}\text { Data } & \text { Informasi } \\
\text { Covid-19 } & \end{array}$ & $2,11^{\prime \prime}$ & $2,44^{\prime \prime}$ & $3,11^{\prime \prime}$ & $2,33 ”$ & $1,21^{\prime \prime}$ & $1,21^{\prime \prime}$ \\
\hline $\begin{array}{l}\text { Peta administrasi Kab } \\
\text { / Kota Prov. Riau }\end{array}$ & $3,12^{\prime \prime}$ & $2,21^{\prime}$ & $3,12 ”$ & $2,11^{\prime}$ & $2,01 ”$ & $1,21 ”$ \\
\hline $\begin{array}{l}\text { Lokasi Pengakses } \\
\text { (Posisi Saya) }\end{array}$ & $1,22 ”$ & $2,12^{\prime}$ & $2.11^{\prime \prime}$ & $1,23 ”$ & 1,11 & $2,11^{\prime}$ \\
\hline Zoom in or Zoom Out & $2,11^{\prime \prime}$ & $2,11^{\prime \prime}$ & $3,11^{\prime \prime}$ & $2,11^{\prime \prime}$ & $1,67^{\prime}$ & $2,12 ”$ \\
\hline Move layer map & $2,11^{\prime \prime}$ & $2,23^{\prime \prime}$ & $2,11^{\prime \prime}$ & $1,22^{\prime \prime}$ & $1,01 ”$ & $1,11^{\prime \prime}$ \\
\hline
\end{tabular}

Dari perhitungan kecepatan akses website map yang telah dibuat kami mendapati bahwasanya penggunakan aplikasi browsing atau mesinpencari yang lebih efisien dalam menghemat waktu mengakses website ini adalah Mozila Firefox dan google chrome untuk digunakan pada perangkat PC. Sedangkan untuk penggunakan dalam mobile atau android aplikasi mesin pencari untuk meng akses website covid 19 ini adalah UC Browser. Penggunaan mesin pencari lainya hanya lambat dalam hitungan detik, tapi tetap mampu menyajikan informasi website SIG Covid 19 yang dibutuhkan oleh pengguna, dalam memantau perkembangan terkini.

\section{KESIMPULAN}

Geografi Sebagai Ilmu yang telah mapan dalam Konsep telah terbukti peranannya dan aplikasinya bagi pembangunan disegala aspek kehidupan manusia. Teknologi SIG semakin menunjukkan taji nya dalam andil menghadapi wabah covid-19 yang menjadi pandemic saat ini. Dari hasil pemetaan serta monitoring persebaran covid-19 di wilayah Provinsi Riau dapat kita simpulkan bahwa besarnya peranan SIG dapat membuktikan perannya dalam mendeskripsikan segala bentuk fenomena yang terjadi di muka bumi, terutama yang menjadi topik pada penulisan ini (Kesehatan). Aplikasi web map yang menginterpretasikan kasus covid-19 ini, diharapkan dapat berkontribusi dalam memberikan data dan informasi yang dibutuhkan masyarakat dalam memonotoring kasus ini. Semoga ini dapat memudahkan pengguna,pemanfaat yang tentu saja akan merasa nyaman dengan aplikasi web ini yang mudah digunakan oleh siapa saja dan bernilai edukatif serta Penyajian Data dan Informasi Covid-19 ini sangatlah interaktif bagi pengguna aplikasi SIG web map dalam menganalisis persebaran kasus tersebut. Dengan adanya aplikasi ini diharapkan dapat membangun informasi yang didapat. Provinsi Riau menjadi fokus penulis dalam menganalis dampak korban jiwa yang diakibatkan oleh covid-19. Terbukti dengan ini dapat berkontribusi dalam memetakan wilayah atau daerah yang menjadi titik perhatian akibat pelaporan kasus yang signifikan jika dilihat dengan daerah yang lainnya di Provinsi Riau.

\section{REFERENSI}

Amalia, Z., Umaroh, A. K., \& Kurniawati, F. (2014). Pemanfaatan Sistem Informasi Geografis Sebagai Informasi StrateSIG Dalam Pengendalian Tuberkulosis. Surakarta. 
Arc-SIG Online Covid-19 Riau berbasis web map 2020.

Adityo Susilo (2020) Coronavirus Disease. 2019 : Tinjauan Literatur Terkini.

BNPB (2012) Peraturan Kepala Badan Nasional Penanggulangan Bencana Indonesia. Kajian Risiko Bencana. Jakarta.

G. Sindhu P.,B Sudarsono ,A. Wijaya (2014). "Rancang Bangun Sistem Informasi Geografis Pelayanan Kesehatan Masyrakat Berbasis Web (Studi Kasus: Kota Semarang) "jurnal Geodesi Undip, vol 3, no 1, Jan.

Longley et al. (2005) dalam buku Geographical Information System and Science 2009. Sistem Informasi Geografis Konsep-Konsep Dasar (Perspektif $\backslash \backslash$ Geodesi \&Geomatika). Bandung: Informatika.

Pratama Rendy OKtafian dan Nita Sekreningsih (2017) Rancang Bangun Sistem Informasi Geografis (SIG) pada Daerah Bencana Kabupaten Madiun Berbasis WebSIG. Journal of Computer and Information Technology E-ISSN: 2579-5317 Vol.1, No. 1, August 2017, Pages 46-51.

Hanif M et al (2019) Multi Spectral Satellite Data to Investigate Land Expansion and Related Micro Climate Change as Threats to the Environment. Journal. IOP Confrence Series: Earth Environ. DOI : 10.1088/1755- 1315/303/1/012030.

Islamadina Raihan dan Nasaruddin (2012) Aplikasi Web Sistem Informasi Geografis Untuk Multi Risiko Bencana Aceh. Jurnal Rekayasa Elektrika Vol. 10, No. 1, April.

Indra Yovi Gugus Tugas Covid-19 Provinsi Riau. (Juni 2020).

Hidayat A R and Hanif M. 2020. Spatial Modeling of The Threat of Damage to The Peatland Ecosystem In The Mainland of Bengkalis Regency, Riau Province. Journal Social Polites. Vol 20. Special Issue. No 2. doi: 10.33541/sp.v21i3.2249

Rahman H, Triyatno, Hanif M, Indrayani P. 2020. Spatial Assessment of Landscape Structure Changes and Ecological Connectivity in Padang Pariaman. Journal of Remote Sensing GIS and Technology. Vol 6- Issue 2. (May-Agust).

Tobler Waldo. 1976. Spatial Intercation Patterns. Department of Geography. Journal of Environmental Systems, VI 94) 77:pp.271-230. 